\title{
Early Life Origins of Asthma: A Review of Potential Effectors
}

\author{
Bobolea $\mathrm{I}^{1-4^{*}}$, Arismendi $\mathrm{E}^{3,4^{*}}$, Valero $\mathrm{A}^{1-4}$, Agustí $\mathrm{A}^{1-4}$ \\ ${ }^{1}$ Respiratory Institute, Hospital Clínic, Barcelona, Spain \\ 2University of Barcelona, Barcelona, Spain \\ 'Institut d'Investigacio Biomedica August Pi i Sunyer (IDIBAPS), Barcelona, Spain \\ ${ }^{4}$ Centro Investigación Biomédica en Red Enfermedades Respiratorias (CIBERES), Spain \\ *Both authors should be considered first authors
}

J Investig Allergol Clin Immunol 2019; Vol. 29(3): 168-179

doi: 10.18176/jiaci.0361

\section{Abstract}

There is growing evidence that events occurring early in life, both before and after birth, are significantly associated with the risk of asthma, chronic obstructive pulmonary disease, and diminished lung function later in life. In fact, from conception to death, a series of continuous, dynamic gene-environment interactions determine 2 fundamental biological processes, namely, lung development and lung aging. Over 130 birth cohorts have been initiated in the last 30 years. Data from these cohorts have improved our understanding of the inception, progression, and persistency of asthma. In this review, we summarize the main data for the early life events proven to determine later development and persistence of asthma, such as maternal atopy and smoking, preterm birth/bronchopulmonary dysplasia, infections, nutrition, obesity, smoking, and other environmental exposures in childhood and adolescence.

While some of these factors are obviously impossible to prevent or eliminate, others have been proven to have a protective role, and current research is aimed optimizing them. Available prophylactic measures are also reviewed. In the case of environmental pollution, large scale political interventions successfully managed to decrease contamination levels, leading to improved lung function and lower asthma prevalence in the respective geographical areas.

Future research should focus on better understanding these complex interactions in order to develop and enhance effective preventive therapeutic measures.

Key words: Atopy. Asthma. Lung function. Pregnancy. Prematurity. Obstructive airway disease. Airway hyperreactivity.

\section{Resumen}

Existe evidencia de que eventos que ocurren en fases tempranas de la vida, tanto antes como después del nacimiento, se asocian significativamente con el aumento del riesgo futuro de asma, enfermedad pulmonar obstructiva crónica y deterioro de la función pulmonar. En efecto, desde el momento de la concepción hasta la muerte, una serie de interacciones dinámicas y continuas genético-ambientales determinan dos procesos biológicos fundamentales, el desarrollo pulmonar y el envejecimiento pulmonar. En los últimos 30 años se han comenzado más de 130 cohortes de nacimiento. Los datos de estas cohortes han mejorado nuestra comprensión del inicio, la progresión y la persistencia del asma. En esta revisión, resumimos los datos principales de los eventos de la vida temprana probados que determinan el desarrollo y la persistencia posteriores del asma, como atopia materna y tabaquismo, parto prematuro/displasia broncopulmonar, infecciones, nutrición, obesidad, tabaquismo y otras exposiciones ambientales en la infancia y la adolescencia.

Si bien algunos de estos factores son obviamente imposibles de prevenir o eliminar, se ha demostrado que otros tienen un papel protector, y la investigación actual apunta a optimizarlos. También se revisan las medidas profilácticas disponibles. En el caso de la contaminación ambiental, las intervenciones políticas a gran escala lograron disminuir los niveles de contaminación, lo que mejoró la función pulmonar y disminuyó la prevalencia de asma en las respectivas áreas geográficas.

Las investigaciones futuras deberían centrarse en comprender mejor estas interacciones complejas para desarrollar y mejorar las medidas terapéuticas preventivas eficaces.

Palabras clave: Atopia. Asma. Función pulmonar. Embarazo. Precocidad. Enfermedad obstructiva de las vías aéreas. Hiperreactividad bronquial. 


\section{Introduction}

Almost 30 years ago, Barker [1] proposed that many adult diseases may have their roots very early in life, during pregnancy, childhood, and/or adolescence. Since then, the so-called Barker hypothesis has been extensively confirmed for several human conditions, and respiratory diseases are no exception [2]. Exposures in fetal and early postnatal life might influence lung growth and development, which can then lead to asthma and chronic obstructive pulmonary disease (COPD) later in life [3-7], as shown by a number of birth cohorts [814] and other epidemiological studies [15-17]. The goal of this review is to summarize current knowledge on a number of potential environmental and genetic factors, which, acting at different time points, can elucidate the early origins of asthma (Table 1).

However, there are 2 important caveats. First, the diagnosis of asthma is quite nonspecific, particularly in children, so many patients with respiratory symptoms may be diagnosed rightly or wrongly with asthma. For instance, a child with impaired lung development is likely to experience some degree of shortness of breath, wheezing, and/or cough, which can easily be misdiagnosed as asthma [18]. Second, the label "asthma" should be the beginning and not the end of the diagnostic process [19], which should try to answer the question What type of asthma does this patient have? [20]. We believe that, in the context of this discussion, both caveats should always be borne in mind.

\section{Genetic Factors}

Asthma is a complex and heterogeneous disease caused by still poorly understood genetic and environmental interactions [21]. The heritability of asthma has been estimated to be around $60 \%[22,23]$, and large-scale

Table 1. Early Life Events in Childhood and Adult Asthma

Prenatal factors
- Genetic
Maternal/pregnancy-related factors
- Atopy
- Nutrition
- Smoking
- Drugs
Perinatal factors
- Preterm birth/Bronchopulmonary dysplasia
- Low birth-weight
Childhood-preschool and school-age infants
- Environmental factors
- The atopic march
- Infections
- Nutrition and obesity
Teenage-young adult
- Smoking
- Hormonal factors
- Occupational agents

Prenatal factors

- Atopy

- Nutrition

- Smoking

- Drugs

Perinatal factors

- Preterm birth/Bronchopulmonary dysplasia

birth-weight

- Environmental factors

- The atopic march

- Infection

- Nutrition and obesity

- Smoking

- Occupational agents genome-wide association studies have identified multiple susceptibility loci [24], although these account for only a modest proportion of the total phenotypic variance. The interleukin (IL) 1 receptor-like 1 gene (ILIRL1), which encodes a member of the Toll-like/IL-1 receptor superfamily expressed in inflammatory and resident cells in the lungs [25] and a single-nucleotide polymorphisms (SNP) in ILIRLI have been associated with time to onset of asthma [25], although this has not been confirmed in other studies [26]. SNPs on chromosome $17 \mathrm{q} 21$ that regulate the expression of at least 1 nearby gene, orosomucoid like 3 (ORMDL3), are also associated with the risk of asthma [21]. Zhang et al [27] showed that ORMDL3 knock-out cells decreased the transcript and protein expression of intercellular adhesion molecule 1 (ICAM1), the major human rhinovirus (HRV) receptor, suggesting a mechanism for the association between $O R M D L 3$, HRV infection, and asthma. Additionally, ICAM1 is a receptor for the bacterial airway pathogen Haemophilus influenzae [28], which is particularly abundant in asthmatic airways between exacerbations [29]. Bouzigon et al [4] investigated the potential role in asthma of 36 SNPs in the $17 \mathrm{q} 21$ region in 1511 patients from 372 families. They showed that these variants were associated with early onset asthma and that they interact with exposure to environmental tobacco smoke. Epigenetic changes (DNA methylation) have also been identified in relation to early onset asthma [15]. In a study of 200 Dutch families (1259 individuals), Kappelman et al [30] found that protocadherin-1 $(P C D H 1)$ was a novel gene (chromosome 5q31-q33) for bronchial hyperresponsiveness in adults and children. Specifically, they showed that $P C D H 1 \mathrm{mRNA}$ and protein were expressed in airway epithelium, the first line of defense against inhaled allergens and toxic substances known to contribute to asthma development. Other genes that have been implicated in the development of childhood asthma are ILI7 and IL23; their genetic variation has been associated with childhood asthma and total levels of serum IgE, the latter of which may be affected by mutations in IL21 and ILIRL1 [31]. IL17, IL21, and $I L 22$ are secreted by $\mathrm{T}_{\mathrm{H}} 17$ cells and are potent inducers of inflammation. Likewise, interactions between maternal oxidative stress response genes (GSTM1, GSTP1, CAT, and $M P O$ ) and maternal prenatal exposure to air pollutants or tobacco smoke can contribute to asthma or allergic airway responsiveness [32].

\section{Maternal/Pregnancy-Related Factors}

\subsection{Atopy}

In a Swiss adult cohort, maternal atopy was associated with a higher prevalence of asthma and allergic rhinitis in offspring [33]. Maternal atopy significantly affected prenatal IgE production, as reflected by elevation of cord blood serum $\mathrm{IgE}$ [32]. Traherne et al [34] showed that a polymorphism of the high-affinity IgE receptor beta-chain (FceRI- $\beta$ ) was strongly associated with positive skin prick test results and greater allergen-specific IgE levels when inherited from mothers. The severity of maternal allergic rhinitis, asthma comorbidity, elevated serum IgE levels, and nasal eosinophilia were all associated with an increased risk of offspring developing 
allergic conditions [35]. On the other hand, Sunyer et al [36] evaluated mothers and their children from the Asthma Multi-centre Infants Cohort Study (AMICS), with the aim of examining the effects of pre- and postnatal environmental exposure in the inception of atopy and asthma. In a study based on 3 European cohorts of pregnant women (Ashford, Kent [UK]; Menorca island [Spain]; and Barcelona city [Spain]), they showed that mothers with allergic sensitization, determined by skin prick test, have a lower number of offspring [36]. Karmaus et al [37] studied the association between maternal atopy and the number of offspring and suggested that a higher number of siblings is protective against the development of atopic manifestation in offspring [37]. The authors proposed that bidirectional maternal-fetal cell trafficking resulting in micro-chimerism occurring during pregnancy and delivery may set up a pocket of nonhost cells that remains in the maternal circulation years after delivery, inducing a range of immune reactions including a reduction in the maternal $\mathrm{T}_{\mathrm{H}} 2$ response in successive pregnancies.

\subsection{Maternal Asthma}

Maternal asthma is the main risk factor associated with the development of early-life asthma [38]. A meta-analysis of 33 studies showed that children with maternal asthma (defined as self-reported physician-diagnosed asthma or as self-reported asthma) had an approximately 3-fold greater risk of asthma than those without maternal asthma [39]. Compared with paternal asthma, maternal asthma was associated with significantly greater odds of childhood asthma $(P=.04)$.

Maternal asthma control during pregnancy is another potential risk factor for asthma in offspring. A higher prevalence of early-onset persistent asthma was observed among children of asthmatic mothers [40] with mild uncontrolled (prevalence ratio [PR], 1.19; 95\% CI, 1.05-1.35), moderate-to-severe controlled (PR, 1.33; 95\%CI, 1.09-1.63), and moderate-to severe uncontrolled asthma (PR, 1.37; 95\%CI, 1.17-1.61), compared with mothers with mild controlled asthma. Hence, maintaining asthma control in pregnancy may be a potential preventive strategy for some specific phenotypes of asthma in offspring [40].

\subsection{Nutrition}

Several studies suggest that the development of asthma is influenced by maternal nutritional status [41]. Turner et al [42] suggested that maternal vitamin E (a-tocopherol) levels may influence lung fetal growth in early pregnancy in a birth cohort of 1924 patients because reduced fetal size in the first trimester was associated with reduced childhood lung function and increased asthma symptoms; maternal vitamin E status appears relevant to this association. Likewise, Wolsk et al [43] combined 2 randomized controlled trials that used prenatal vitamin $\mathrm{D}(25(\mathrm{OH}) \mathrm{D})$ supplementation during pregnancy $[44,45]$ and showed that it reduced the risk of asthma/recurrent wheeze in offspring, particularly among women with vitamin D levels $\geq 30 \mathrm{ng} / \mathrm{mL}$ at randomization, where risk was almost halved. On the other hand, a prospective pre-birth cohort study of participants unselected for atopic propensity found that higher maternal intake of allergenic foods (peanuts) during the first trimester of pregnancy was associated with a $47 \%$ reduction in the odds of childhood peanut allergic reaction, maternal milk intake during the first trimester was associated with reduced odds of childhood asthma and allergic rhinitis, and maternal intake of wheat during the second trimester was associated with reduced childhood atopic dermatitis [46].

\subsection{Infections}

Maternal infections during pregnancy, including respiratory tract infections, febrile infectious diseases, urinary tract infections, and vaginitis, are associated with a higher risk of childhood asthma [41]. Chorioamnionitis is a common cause of in utero inflammation (ie, presence of inflammation within fetal membranes), and neonates born from mothers with chorioamnionitis are at increased risk of mortality and of developing significant lung morbidity, including acute respiratory distress syndrome, bronchopulmonary dysplasia (BPD), reactive airway disorders, and an increased risk of preterm infants for developing asthma, even after correction for confounding factors [47].

Other infections have also been associated with an increased risk of asthma in children, but the overarching mechanisms by which maternal infections result in increased risk of childhood asthma remain unclear. The so-called hygiene hypothesis proposes that allergic sensitization starts in utero, so the asthma phenotype is programmed before birth and the exposure to endotoxins and other microbial products after birth influences the innate immune system [41] and modifies the lung microbiome, thus contributing to asthma [48]. In a study of 910301 children born in Denmark between 1997 and 2010, Stokholm et al [49] showed that maternal use of antibiotics in pregnancy was associated with an increased risk of childhood asthma.

\subsection{Tobacco Smoking}

Tobacco smoking continues to be a major prenatal problem in the USA, with $10 \%-12 \%$ of women admitting smoking tobacco during pregnancy [50]. Despite widely available evidence of the deleterious impact of in utero tobacco exposure on fetal development, approximately half of women smokers continue to smoke during early pregnancy [50]. Many studies have now clearly demonstrated that maternal smoking during pregnancy results in abnormal lung function in offspring and that this tracks into childhood and adult life [51]. Burke et al [52] performed a meta-analysis of 71 studies of environmental tobacco smoke, wheeze, and asthma. Pre- and postnatal passive exposure to tobacco smoke was associated with a $30 \%$ to $70 \%$ increased risk of incident wheezing. Exposure to prenatal maternal smoking was associated with a $40 \%$ increase in risk of wheeze in children aged $\leq 2$ years (OR, 1.41; $95 \%$ CI, 1.20-1.67; I2=82.5\%; 14 studies). A similar effect size was observed for the association between prenatal maternal smoking and incidence of wheeze between the ages of 3 and 4 (OR, 1.28; 95\%CI, 1.14-1.44; $\mathrm{I}^{2}=65.5 \%$; 8 studies). Prenatal passive exposure to tobacco smoke was associated with a $52 \%$ increased risk of wheeze in children aged 5 to 18 years (OR, $1.52 ; 95 \% \mathrm{CI}, 1.23-1.87 ; \mathrm{I} 2=21.1 \% ; 5$ studies $).$ In summary, exposure to passive smoking increases the incidence of wheeze 
and asthma in children and young people by at least $20 \%$ [52]. More recently, Dehmel et al [53] used an animal model to highlight a potential novel link between smoke exposure, aberrant lung development and impaired lung function. These authors showed that prenatally exposed mice had intrauterine and postnatal growth retardation and impaired lung function, that 1340 genes and 133 miRNAs were significantly dysregulated, and that insulin-like growth factor 1 (IGF-1) was a top hierarchical node in their network analysis. Moreover, IGF-1 mRNA was increased in female murine offspring and in prenatally exposed children, suggesting that prenatal smoking is associated with dysregulation of several genes, including IGF-1 in a sex-specific manner [53].

The nicotine replacement therapy is controversial. Molero et al [54] observed that parental varenicline treatment was associated with a lower rate of visits for bronchitis/ bronchiolitis in children (incidence rate ratio [IRR], 0.67; 95\% CI, 0.50-0.91), but no association was found for asthma (IRR, 1.08; 95\%CI, 0.97-1.19). The reduction in the rate of bronchitis/bronchiolitis was similar when data were restricted to children aged $0-3$ years (IRR, $0.71 ; 95 \% \mathrm{CI}, 0.52-0.97$ ) and to maternal varenicline treatment (IRR, 0.64; 95\%CI, 0.43-0.96). When restricting the outcomes to unplanned visits only (ie, excluding booked appointments, follow-ups, and referrals), no associations were found (IRR, $0.72,95 \% \mathrm{CI}, 0.51-1.02$ ).

Finally, exposure to tobacco smoke increases the incidence of wheeze and asthma in children and young people, and maternal nicotine replacement therapy is associated with a reduction in the number of visits for bronchitis/bronchiolitis in offspring.

\subsection{Drugs}

Antibiotic use $[55,56]$ has been associated with an increased risk of childhood asthma. The Copenhagen Prospective Study on Asthma in Childhood data showed increased risk of asthma exacerbation (HR, 1.98; 95\%CI, 1.08-3.63) in mothers who used antibiotics during the third trimester [55]. The Danish National Birth Cohort confirmed the increased risk of asthma hospitalization (HR, 1.17; 95\%CI, 1.00-1.36), and inhaled corticosteroid use (HR, 1.18; 95\%CI, 1.10-1.27) in children below the age of 5 if mothers used antibiotics at any time during pregnancy. In the subgroup of mothers who used antibiotics for nonrespiratory infection, children also had an increased risk of asthma, which supports a role for bacterial ecology in the development of asthma in pre- or perinatal life. Finally, a meta-analysis of 10 studies [56] investigating the potential role of antibiotic exposure showed an OR of 1.20 (95\%CI, 1.131.27) for wheeze/asthma. After excluding case-control studies and prospective studies without achieving high scores on the Newcastle-Ottawa Quality Assessment Scale, the pooled OR was 1.18 (95\%CI, 1.11-1.26), and the risk of antibiotic use varied according to the time of exposure, with pooled ORs for wheeze/asthma of 1.09 (95\%CI, 0.92-1.29) for the first trimester, $1.14(95 \% \mathrm{CI}, 1.01-1.29)$ for the second trimester, and $1.33(95 \% \mathrm{CI}, 1.11-1.60)$ for the third trimester. All in all, these observations indicate that exposure to antibiotics during pregnancy increases the risk of wheeze/asthma in childhood, particularly during the last 2 trimesters of pregnancy [56].

By contrast, the potential effects of maternal paracetamol use during pregnancy on the risk of asthma of offspring are controversial. On the one hand, Cheelo et al [57] evaluated 11 observational cohort studies and concluded that there was insufficient evidence to warrant changing guidelines on early life exposure to paracetamol. On the other, another metaanalysis of 6 studies by Eyers et al [58] concluded that the use of paracetamol during all trimesters of pregnancy was indeed associated with an increased risk of childhood asthma (OR, 1.21; 95\%CI, 1.02-1.44)

\section{Perinatal Factors: The "Birth Lung"}

\subsection{Preterm Birth: Bronchopulmonary Dysplasia}

BPD is a chronic respiratory disease associated with premature birth that primarily affects infants born at less than 28 weeks' gestational age. BPD also develops in approximately $10 \%$ to $40 \%$ of very low birth weight and extremely low birth weight infants, respectively, with 5000 to 10000 new cases in the USA each year [59]. BPD is associated with a later risk of asthma [60] and airflow limitation in adults [61,62]. For instance, in the European Community Respiratory Health Survey, adults with a history of BPD were twice as likely to report wheeze and 3 times more likely to use asthma medications than full-term controls [63]. Indeed, the severity of BPD is also an important predictor of health care utilization between the ages of 8 and 15 years [62]. A recent meta-analysis quantified $\mathrm{FEV}_{1}$ deficit in later life in a number of different groups of patients born before term and confirmed that, even in those without BPD, the $\mathrm{FEV}_{1}$ percentage was lower than in the population born at term [5].

\subsection{Low Birth Weight}

Early life growth patterns have been associated with increased risk of respiratory morbidity later in life $[6,64]$. Recently, den Dekker et al [6] showed that both restricted and accelerated fetal growth predispose children to poorer lung function and respiratory diseases later in life. Specifically, this study showed that between birth and age 3 months, restricted weight gain was associated with an increased risk of childhood asthma (OR, 1.57; 95\%CI, 1.01-2.45). Similarly, accelerated weight gain was associated with lower $\mathrm{FEV}_{1}, \mathrm{FEV}_{1} / \mathrm{FVC}$, and $\mathrm{FEF}_{75}$ than normal weight gain.

Very low birth weight $(<1500 \mathrm{~g})$ has been associated with poor lung function at 6-12 months of corrected age [65]. Birth weight is associated with lung function in term-born children at 8-9 years, but less so at 14-17 years. Consequently, it seems that birth weight influences lung function in early childhood but has a lesser effect later in life. A meta-analysis of 147000 European children [64] assessed the association between childhood asthma outcomes and preterm birth (gestational age $<37$ weeks) and low birth weight $(<2500 \mathrm{~g})$ and concluded that younger gestational age at birth and higher infant weight gain were independently associated with higher risks of preschool wheezing and school-age asthma $(P<.05)$. Compared with term-born children with normal infant weight gain, the highest risks of school-age asthma were observed in children born preterm with high infant weight gain (OR, 4.47; 95\%CI, 2.587.76). Preterm birth was positively associated with an increased risk of preschool wheezing (pooled odds ratio [pOR], 1.34; 
95\%CI, 1.25-1.43) and school-age asthma (pOR, 1.40; 95\%CI, 1.18-1.67), independently of birth weight.

Finally, fetal size also has been associated with increased risk of childhood asthma [48]. Turner et al [66] showed that each reduction in the $\mathrm{z}$-score for first trimester size was associated with increased odds for dispensed asthma medication at 15 years of age (OR, 1.26; 95\% CI, 1.03-1.54) and self-reported use of asthma medications (OR, 1.55; $95 \% \mathrm{CI}, 1.16-2.08)$. In that study, investigators also measured the crown-rump length in the first trimester and the biparietal diameter and femur length in the second trimester, performed spirometry (at 5, 10, and 15 years of age), and collected data about asthma medication. The results showed that first and second trimester size and $\mathrm{FEV}_{1}$ at ages 5, 10, and 15 years were reduced for those dispensed asthma medications compared with those not dispensed asthma medications $(P=.003)[66]$.

\section{Childhood, Preschool, and School-Age Infant}

At this point, it is important to differentiate between risk factors for asthma development and those that may aggravate early onset asthma, although some factors (eg, allergens, respiratory infections, and environmental pollution) can influence both. For instance, birth cohorts identified early allergic sensitization [67] and rhinovirus infections with wheezing in infancy [68] as major triggers of asthma exacerbations later in life [69] and strong predictors of the subsequent development of asthma. Based on all these findings, the current concern focuses on prevention as a potential approach for the primary prophylaxis of childhood asthma and/or poor lung function in adult life [70].

\subsection{Environmental Factors: Protective and Enhancing Effects for the Risk for Asthma}

Air pollution increases the risk for asthma attacks [71] and for asthma hospitalizations [72]. Reductions in peak expiratory flow, increases in respiratory symptoms, and asthma medication use were reported in patients with asthma exposed to elevated fine particulate pollution levels [73]. These results, added to those from a large number of similar studies worldwide, have contributed to environmental policy changes that in turn have resulted in significant improvements in lung function in children [74]. In Southern California, Gauderman et al [74] measured lung function annually in 2120 children from 3 separate cohorts corresponding to 3 separate calendar periods: 1994-1998, 1997-2001, and 2007-2011. The mean age of the children within each cohort was 11 years at the beginning of the period and 15 years at the end. Over the 13 years spanned by the 3 cohorts, declining atmospheric levels of nitrogen dioxide, particulate matter with an aerodynamic diameter of less than $2.5 \mu \mathrm{m}$ and less than $10 \mu \mathrm{m}$ were significantly associated with improvements in both $\mathrm{FEV}_{1}$ and FVC. These associations persisted after adjustment for several potential confounders and were observed both in boys and girls, as well as in children with and without asthma. The proportions of children with low $\mathrm{FEV}_{1}$ (defined as $<80 \%$ of the predicted value) at 15 years of age declined significantly from $7.9 \%$ to $6.3 \%$ to $3.6 \%$ across the 3 periods as the air quality improved $(P=.001)$.

Shortly after the reunification of Germany in 1989, von Mutius et al [75] reported that the prevalence of current asthma and bronchial hyperresponsiveness was significantly higher in West than in East Germany. Higher exposure to endotoxins at home was found to be protective against the development of allergic sensitization in children. These results opened a new field, namely, the search for protective environmental exposures in early life that could prevent subsequent asthma. In this context, living on a farm during infancy has been found to be associated with a lower risk of asthma in adulthood. A prospective longitudinal association between exposure to a farming environment during infancy and lung function in adulthood was studied in a Finnish birth cohort study [76]. A total of 5666 participants born in 1966 were followed up until the age of 31 years. Being born in a farmer's family was associated with higher $\mathrm{FEV}_{1}$ and $\mathrm{FVC}$ at the age of 31 years, and contact with farm animals during infancy was associated with higher $\mathrm{FEV}_{1}$. There was a suggestive dose-dependent association with the number of animal species during childhood and higher $\mathrm{FEV}_{1}$ and FVC during adulthood, especially among women. The study concluded that exposure to a farming environment in early life may have a positive impact on lung function in adulthood. In summary, environmental measures aimed at reducing air pollution and a more rural, less industrialized environment in childhood improve lung function in adults.

\subsection{Atopy, Allergy, Eczema: The Atopic March}

The classic Tucson birth cohort study proposed 3 categories of wheezing phenotypes at an early age: transient wheezers (wheezing symptoms before 3 years, no wheezing at age 6), lateonset wheezers (no wheeze until 3 years, wheezing at age 6), and persistent wheeze (wheezing in the first 3 years, wheezing at 6 years) [79]. Persistent wheezers can be further subdivided into atopic and nonatopic. One third of all children aged 3 or younger had lower respiratory tract illnesses with wheezing; however, by the age of 6 , close to $60 \%$ of these children no longer had wheezing symptoms. Transient early wheezers were found to have poorer lung function than other groups of wheezers, possibly reflecting congenitally smaller airways.

These observations enabled the development of an asthma predictive index [77], which has been further used in major clinical trials $[78,79]$ to identify young children at high risk for the disease. A stringent index included frequent wheezing during the first 3 years of life and either 1 major risk factor (parental history of asthma or eczema) or 2 of 3 minor risk factors (eosinophilia, wheezing without colds, and allergic rhinitis). A loose index required any wheezing during the first 3 years of life plus the same combination of risk factors described previously. Children with a positive loose index were 2.6 to 5.5 times more likely to have active asthma between ages of 6 and 13 than children with a negative loose index [77]. Risk of having subsequent asthma increased from 4.3 to 9.8 times when a stringent index was used.

In the Tucson Children's Respiratory Study (CRS), a nonselected birth cohort, early sensitization to Alternaria species was associated with increased airway hyperresponsiveness 
(AHR) in adult life among nonasthmatics. The increase in AHR was of a similar magnitude to that seen for Alternaria-sensitized asthmatics and was primarily evident among those who were overweight or obese. In contrast, there was no significant association between early sensitization to aeroallergens other than Alternaria and AHR among nonasthmatics [80]. These observations indicate that, in clinical practice, physicians should always ask about the "atopic march" (atopic dermatitis, food allergy, and allergic rhinitis) in childhood. Independently of other factors, this provides valuable information about a potential T2 signature for the individual. Yet, the relationship between the level of exposure and sensitization varies widely between studies, from a nonsignificant association to a simple linear dose-response relationship or a "bell-shaped" dose-response model with a protective effect of high allergen exposure. A 2009 Cochrane review found that multifaceted interventions (reducing exposure to both inhalant and food allergens) resulted in a significant decrease in asthma compared to usual care $(<5$ years: OR, 0.72 [95\%CI, $0.54-$ 0.96 ]; $>5$ years: OR, 0.52 [95\%CI, 0.32-0.85]) [81]. There is also growing evidence on the potential of immunotherapy to alter the natural course of the atopic march from allergic sensitization to asthma. A recent study included 812 children (aged 5-12 years) with grass pollen-allergic rhinoconjunctivitis and no medical history or signs of asthma. The children were studied in a double-blinded fashion, randomly allocated to receive immunotherapy or placebo for 3 years, and followed for an additional 2 years [82]. The study showed a reduced risk of experiencing asthma symptoms and using asthma medication, but did not show an effect on the time to onset of asthma. Hence, the relationship between allergic desensitization and asthma is complex and seems to depend on other environmental factors and individual genetic predispositions. Thus, the role of and the measures used for prevention of sensitization in the development of IgE-mediated asthma have yet to be determined.

More recently, the association between nonallergic rhinitis in early life and subsequent asthma was explored in the Tucson CRS [83]. Allergy skin prick testing was performed at age 6, atopy being defined as $\geq 1$ positive test results. Physiciandiagnosed active asthma from age 6 to 32 years and physiciandiagnosed rhinitis at age 6 were determined by questionnaire. Participants with asthma or active wheezing at age 6 were excluded from the analyses. A total of 521 participants met the inclusion criteria. The results showed that the hazard ratio for subsequently acquiring a diagnosis of asthma between the ages of 8 and 32 for those with nonatopic rhinitis was 2.1 (95\%CI, 1.2-3.4); $P=.005)$, compared with the nonatopic, nonrhinitis group after adjusting for sex, ethnicity, maternal asthma, maternal education, smoking, and history of $>4$ colds per year at age 6 . Among the atopic participants, both the active and nonrhinitis groups were more likely to develop and have asthma up to age 32 . The relationship between nonatopic rhinitis and asthma was independent of total serum IgE levels at age 6 . In conclusion, early rhinitis, whether allergic or nonallergic, confers significant risk for development of asthma through adulthood. These findings underscore the importance of nonallergic mechanisms in the development of asthma (see below).

\subsection{Infections: Respiratory Syncytial Virus, Rhinovirus, and "The Viral March"}

A better understanding of the "viral march" could yield new therapeutic approaches for the prevention and treatment of acute severe airway obstruction during childhood. Most infants aged $<1$ year who wheeze remit by the age of 3 (the so-called transient wheezers), and their episodes are associated with viral infections. Young children who develop asthma later in life usually experience recurrent episodes of wheezing, cough, and difficulty breathing (persistent wheezers), and these episodes are associated with molecular evidence of viral respiratory infection in up to $90 \%$ of cases [70]. Currently, it is widely recognized that early life respiratory syncytial virus (RSV) and HRV lower respiratory tract infections (LRTIs) are strongly associated with increased asthma risk. During early infancy, RSV is a more common cause of severe LRTIs. Severe $\mathrm{RSV}$ bronchiolitis requiring hospitalization is considered a risk factor for future asthma. With advancing age, the situation is reversed, with HRV becoming more common.

In a recent Finnish study, 127 corticosteroid-naive children with the first severe wheezing episode $(90 \%$ hospitalized $/ 10 \%$ emergency department-treated) were followed for 7 years. The primary outcome was current asthma at age 8 years. At study entry, median age was 11 months, $17 \%$ were sensitized, and $98 \%$ were virus-positive. Current asthma $(n=37)$ at 8 years was divided into atopic asthma $(\mathrm{n}=19)$ and nonatopic $(\mathrm{n}=18)$ asthma. The risk factors for current atopic asthma at study entry were sensitization (adjusted OR, 12; $P<.001$ ), eczema (adjusted OR, 4.8; $P=.014$ ), and wheezing with rhinovirus (adjusted $\mathrm{OR}, 5.0 ; P=.035)$. The risk factors for nonatopic asthma were the first severe RSV/rhinovirus-negative wheezing episode (adjusted OR, 8.0; $P=.001$ ), first wheezing episode at age less than 12 months (adjusted OR, 7.3; $P=.007$ ), and parental smoking (adjusted OR, 3.8; $P=.028$ ) [84].

Even more so, the CRS Tucson cohort aimed to determine whether there were individuals with a distinct, persistently poor lung function trajectory [85]. A total of 1246 participants included between 1980 and 1984 were followed prospectively; distinct lung function trajectories were observed among participants with 2 or more spirometry measurements between ages 11 and 32 years. Among 599 participants, a model with 2 distinct trajectories (a low trajectory $[\mathrm{n}=56 ; 9.3 \%]$ and a normal trajectory) fit the data significantly better than a model with only 1 trajectory $(P=.0007)$. As compared with those with a normal trajectory, participants with a persistently low trajectory were more likely to have a history of maternal asthma (20.0\% vs $9.9 \% ; P=.02)$, early life lower respiratory illness caused by RSV (41.2\% vs $21.4 \% ; P<.001)$, and physiciandiagnosed active asthma at age 32 years $(43.9 \%$ vs $16.2 \%$; $P<.001)$. Of all these factors, early RSV is obviously the only preventable one.

Hence, these findings are important for designing early intervention strategies for prevention of asthma. Currently, the role of strategies to prevent RSV infection (palivizumab, azithromycin, specific vaccine) has yet to be confirmed. In a study of 937 young children with histories of recurrent severe LRTIs, for instance, the use of azithromycin early during an apparent RTI compared with placebo reduced the likelihood of severe LRTI, with no significant adverse events. More 
information is needed on the development of antibioticresistant pathogens with this strategy [86]. As for HRV, strategies for developing an effective vaccine or for preventing viral contact and invasion by forming a barrier on the host mucosa are being developed; however, there is currently no approved strategy against HRV. Limiting viral spread is the main available protective measure.

\subsection{Nutrition and Obesity}

Given that dietary interventions in childhood are attractive and inexpensive, they are being intensively investigated. More than 2 decades ago, Hodge et al [87] examined the relationship between consumption of certain foods and asthma and found a significantly reduced risk of current asthma in children who ate fresh, oily fish (OR, 0.26; 95\% CI, 0.09-0.72;P<.01). Vitamin D is associated with asthma, although evidence for its role in primary prevention is still lacking. Other vitamins (such as $\mathrm{C}$ and $\mathrm{E}$ ) failed to show a beneficial effect.

On the other hand, overweight/obesity is linked to worse asthma and a poorer response to inhaled corticosteroid (ICS) response in older children and adults. A post hoc study of 3 large NIH/NHL multicenter trials involving children aged 2 to 5 years compared annualized asthma symptom days and exacerbations among normal weight participants (body mass index, 10th-84th percentiles) with overweight participants (body mass index, $\geq 85$ th percentile). Within the group not treated with a daily controller, overweight children had more asthma symptom days $(90.7$ vs $53.2, P=.020)$ and exacerbations ( 1.4 vs $0.8, P=.009)$ than normal weight children. Within the ICS-treated groups, both overweight and normal weight children had similar asthma symptom days and similar exacerbations [88]. Therefore, unlike older asthmatic patients, overweight preschool children do not demonstrate reduced responsiveness to ICS therapy. Nonetheless, early primary and secondary prevention of obesity, a real epidemic, is of the utmost importance from numerous points of view related to health outcomes and quality of life at any age.

\section{Teenager/Young Adult}

Puberty is accompanied by a series of factors that come into play and complicate the puzzle of the early life origins of asthma. The most relevant are tobacco smoking, hormonal changes, and exposure to occupational agents.

\subsection{Smoking}

Several reports have suggested that, among active tobacco smokers, previous exposure to parental smoking may increase susceptibility to COPD. This was assessed prospectively using data from the Tucson Children's Respiratory Study [91]. Maternal and paternal smoking were assessed via questionnaires completed by the parents at the time of the participant's birth. Active smoking in study participants was assessed via personal questionnaires completed at ages 16,22 , and 26 years. Participants were stratified into 4 groups based on the combination of parental and active smoking. Lung function parameters, including $\mathrm{FEV}_{1} / \mathrm{FVC}$, were assessed by spirometry before and after inhalation of $180 \mu \mathrm{g}$ of albuterol at years 11, 16, 22, and 26. Complete data were available for 519 participants. Prebronchodilator $\mathrm{FEV}_{1} / \mathrm{FVC}$ values did not differ at year 11,16 , or 22 by parental or active smoking. However, at year 26, participants with exposure to parental and active smoking had prebronchodilator $\mathrm{FEV}_{1} / \mathrm{FVC}$ levels that were, on average, $2.8 \%(0.9 \%-4.8 \% ; P=.003)$ lower than those of participants who were not exposed to parental or active smoking. In contrast, participants who were only exposed to active smoking or only exposed to parental smoking did not differ from those who were not exposed to either. Between years 11 and 26, participants with exposure to parental and active smoking had the steepest decline in sex-, age-, and heightadjusted residuals of $\mathrm{FEV}_{1} / \mathrm{FVC}, \mathrm{FEV}_{1}$, forced expiratory flow between $25 \%$ and $75 \%$ of the $\mathrm{FVC}\left(\mathrm{FEF}_{25-75}\right)$, and $\mathrm{FEF}_{25-75} / \mathrm{FVC}$ (all $P$ values between .03 and $<.001$ ). In conclusion, parental and active smoking act synergistically with respect to early lung function deficits in young adulthood [89].

The role of viral infections in the development of early asthma has been discussed. In addition, it seems that smoking is particularly dangerous in patients with diseases caused by RSV in early life [90]. A total of 1246 nonelected infants from the Tucson cohort were enrolled at birth and prospectively followed. Virologically confirmed previous RSV infections were assessed during the first 3 years of life. At ages 22, 24, 26, and 29 years, current asthma and smoking behavior were evaluated by questionnaire. Peak flow variability was assessed at age 26 and expressed as amplitude \% mean. A longitudinal analysis was used to investigate the relationship between RSVLRTI and active smoking and adult outcomes. Neither RSV nor active smoking was directly associated with increased current adult asthma or peak flow variability. However, there was a significant interaction between RSV-LRTI and active smoking in relation to current asthma ( $P$ for interaction, .004) and peak flow variability ( $P$ for interaction, .04). Among patients with early RSV-LRTI, those who actively smoked were 1.7 times more likely to have current asthma $(95 \% \mathrm{CI}$, $1.2-2.3 ; P=.003)$ and had a greater amplitude $\%$ mean than nonsmokers $(10.0 \%$ vs $6.4 \% ; P=.02)$. Therefore, smoking is associated with an increased risk of asthma in young adults who had RSV-LRTI in early life, but not among individuals without this condition. There is no question that smoking is a preventable and modifiable risk factor in asthma. Robust measures are required to reduce prenatal and postnatal smoking as a strategy for primary prevention of asthma.

\subsection{Hormonal Factors}

Little is known about predictors of remission of childhood asthma after the onset of puberty. To investigate this question, data were collected from 781 children of the Tucson Children's Respiratory Study at ages 6, 8, 11, 13, and 16 years [91]. Of these 781 children, 166 had asthma in at least 1 survey before puberty. In this group, $58 \%$ of the children reported the presence of wheezing after the onset of puberty (unremitting asthma). In contrast, only $30 \%$ of the children with infrequent wheezing before puberty experienced wheezing episodes after the onset of puberty (unremitting wheezing). In addition to frequent wheezing before puberty, independent predictors of unremitting asthma after the onset of puberty comprised 
obesity, early onset of puberty, active sinusitis, and positive skin test results [91].

In addition, accumulating evidence indicates that hormonal factors play a role in new-onset allergic rhinitis and asthma after puberty. A large prospective community-based cohort study performed in Germany followed 1191 girls aged 9 to 11 years to early adulthood (19-24 years old) [92]. Data on age at menarche, use of hormonal contraceptives, and status and age at onset of physician-diagnosed allergic rhinitis and asthma were collected at 16 to 18 and 19 to 24 years of age. Allergic rhinitis was observed in $11 \%$ of girls after menarche, and $3 \%$ reported new-onset asthma. Late menarche $(>13$ years of age) was statistically significantly inversely related to allergic rhinitis (adjusted OR, 0.32; 95\% CI, 0.14-0.74) but did not reach the level of statistical significance for asthma (OR, $0.32 ; 95 \% \mathrm{CI}, 0.07-1.42)$. Use of hormonal contraceptives was inversely associated with new-onset allergic rhinitis (OR, 0.14; 95\% CI, 0.08-0.23) and asthma (OR, 0.27; 95\%CI, 0.12-0.58) after puberty. These results show that girls with late onset of menarche are less likely to develop allergic rhinitis after puberty than those who have menarche at an average age. These findings also suggest that hormonal contraceptives might protect young women from allergies and asthma [92]. However, further evidence is required before recommendations on prevention can be made.

\subsection{Occupational Agents}

In genetically predisposed individuals, certain occupations, such as baker, hairdresser, cleaner, and construction or car industry workers (especially those exposed to isocyanates [paint, varnish]), carry a risk of occupational asthma, as is nowadays well recognized by both physicians and labor laws. Poor clinical outcomes and levels of lung function in these individuals might be aggravated by other early life disadvantages, such as parental or active patient smoking at an early age, infections, poor medical attention and lack of appropriate treatment in low-income countries, or a combination of these factors. Long-term exposure to the occupational agent (eg, in persons who start work at a very young age and/or cannot change their workplace when the symptoms start) could play a role. For instance, a crosssectional study performed in 13499 cleaners in Northern Europe investigated whether early life factors influenced susceptibility to the unhealthy effects of occupational cleaning [93]. Associations with respiratory symptoms, asthma, and self-reported COPD were analyzed with multiple logistic regression adjusted for sex, age, smoking, educational level, parents' educational level, body mass index, and participating center. The interaction between occupational cleaning and early life disadvantage (maternal smoking, severe respiratory infection $<5$ years, birth during winter months, maternal age at

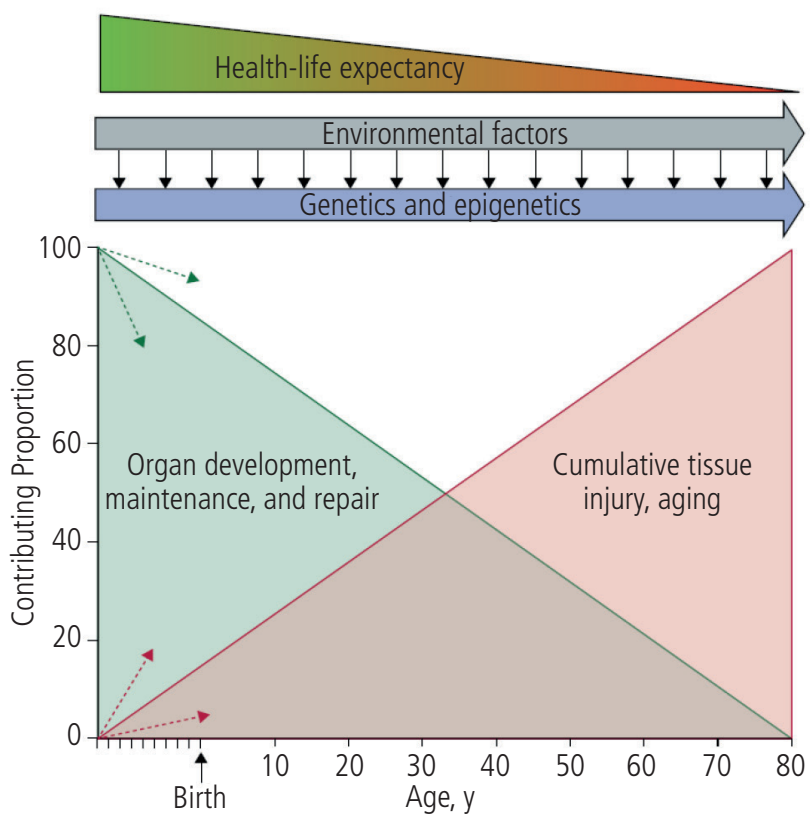

Figure. Interplay between organ development, maintenance, and repair (green triangle) and cumulative tissue injury and aging (red triangle). Dashed arrows (green and red) indicate that the slope of these lines can vary (for better or worse) in different individuals. This interplay over a lifetime determines health and life expectancy (top triangle). For further explanations, see text. Reproduced with permission from reference [94].

Table 2. Factors That Influence Asthma development in Chronological Order

\begin{tabular}{|c|c|c|c|}
\hline Perinatal Factors & References & $\begin{array}{l}\text { Childhood and Adolescence } \\
\text { Factors }\end{array}$ & References \\
\hline $\begin{array}{l}\text { Prenatal factors: } \\
\text { - Genetic factors }\end{array}$ & $4,21-31$ & $\begin{array}{l}\text { Preschool and School-age Infants } \\
\text { Environmental factors during childhood }\end{array}$ & \\
\hline $\begin{array}{l}\text { Maternal factors: } \\
\text { - Atopy } \\
\text { - Asthma } \\
\text { - Nutrition } \\
\text { - Infections } \\
\text { - Smoking } \\
\text { - Drugs }\end{array}$ & $\begin{array}{c}32-37 \\
9,40 \\
42-46 \\
47-49 \\
51-54 \\
55-58\end{array}$ & $\begin{array}{l}\text { - Air pollution } \\
\text { - Urban versus Rural lifestyle } \\
\text { Early events } \\
\text { - Atopy/allergy } \\
\text { - Infections } \\
\text { - Nutrition } \\
\text { Teenage years-young adulthood }\end{array}$ & $\begin{array}{c}70-73 \\
70,74-75 \\
66,76,79-81 \\
67,84,85 \\
86,87\end{array}$ \\
\hline $\begin{array}{l}\text { Perinatal factors: } \\
\text { - Preterm birth/BPD } \\
\text { - Low birth-weight }\end{array}$ & $\begin{array}{l}5,59-63 \\
64-66\end{array}$ & $\begin{array}{l}\text { - Smoking } \\
\text { - Hormones } \\
\text { - Occupational exposure }\end{array}$ & $\begin{array}{c}88,89 \\
90,91 \\
92\end{array}$ \\
\hline
\end{tabular}


birth $>35$ years) was investigated. Among 2138 persons who had worked as cleaners, the risks of wheeze (OR, $1.4 ; 95 \% \mathrm{CI}$ 1.3-1.6), adult-onset asthma (1.5 [1.2-1.8]), and self-reported COPD (1.7 [1.3-2.2]) were increased. The risk increased with years in occupational cleaning (adult-onset asthma: $\leq 1$ year 0.9 [0.7-1.3]; $1-4$ years $1.5[1.1-2.0] ; \geq 4$ years $1.6[1.2-2.1])$. The association between wheeze and working as a cleaner for $\geq 4$ years was significantly stronger among those with early life disadvantage than in those without $(1.8$ [1.5-2.3] vs 1.3 [0.96-1.8]; $P$ value for the interaction, 0.035$)$. These results indicate that ooccupational cleaners had an increased risk of asthma and self-reported COPD, particularly those with early life disadvantage.

\section{Conclusions}

There is now overwhelming evidence that events occurring early in life, both before and after birth, are significantly associated with the risk of asthma and poor lung function later in life. In fact, from conception to death, numerous continuous, dynamic gene-environment interactions (Table 2) determine 2 fundamental biologic processes, namely, lung development and lung aging (Figure). The interaction of these 2 processes determines the presence or absence of early or late respiratory (and other) diseases [94]. Future research should focus on better understanding these complex interactions in order to develop more effective preventive and accurate therapeutic measures [95].

\section{Funding}

The authors declare that no funding was received for the present study.

\section{Conflicts of Interest}

The authors declare that they have no conflicts of interest.

\section{References}

1. Barker DJ. The fetal and infant origins of adult disease. BMJ. 1990:301:1111.

2. Duijts L. Fetal and infant origins of asthma. Eur J Epidemiol. 2012;27:5-14.

3. Martinez FD, Guerra S. Early Origins of Asthma. Role of Microbial Dysbiosis and Metabolic Dysfunction. Am J Respir Crit Care Med. 2018;197:573-9.

4. Bouzigon $E$, Corda $E$, Aschard $H$, Dizier $M-H$, Boland $A$, Bousquet J, et al. Effect of 17q21 Variants and Smoking Exposure in Early-Onset Asthma. New Eng J Med. 2008;359: 1985-94.

5. Kotecha SJ, Edwards MO, Watkins JW, Henderson JA, Paranjothy S, Dunstan FD, et al. Effect of preterm birth on later FEV1: a systematic review and meta-analysis. Thorax. 2013:68:760-6.

6. den Dekker HT, Jaddoe VWV, Reiss IK, de Jongste JC, Duijts L Fetal and Infant Growth Patterns and Risk of Lower Lung Function and Asthma. The Generation R Study. Am J Respir Crit Care Med. 2018;197:183-92.
7. Örtqvist AK, Ullemar V, Lundholm C, Kuja-Halkola $R$, Magnusson PKE, Lichtenstein $P$, et al. Fetal Growth and Childhood Lung Function in the Swedish Twin Study on Prediction and Prevention of Asthma. Ann Am Thorac Soc. 2017:14:1147-53.

8. Taussig LM, Wright AL, Morgan WJ, Harrison HR, Ray CG. The Tucson Children's Respiratory Study. I. Design and implementation of a prospective study of acute and chronic respiratory illness in children. Am J Epidemiol. 1989;129:121931.

9. Hofman A, Jaddoe VWV, Mackenbach JP, Moll HA, Snijders RFM, Steegers EAP, et al. Growth, development and health from early fetal life until young adulthood: the Generation $\mathrm{R}$ Study. Paediatr Perinat Epidemiol. 2004;18:61-72.

10. Cauwenberge VP, Watelet JB, Zele VT, Bousquet J, Burney P, Zuberbier T Spreading excellence in allergy and asthma: the GA2LEN (Global Allergy and Asthma European Network) project. Allergy. 2005;60:858-64.

11. Keil T, Kulig M, Simpson A, Custovic A, Wickman M, Kull I, et al. European birth cohort studies on asthma and atopic diseases: II. Comparison of outcomes and exposures - a GA2LEN initiative. Allergy. 2006;61:1104-11.

12. Tischer CG, Hohmann C, Thiering E, Herbarth 0 , Müller A, Henderson J, et al. Meta-analysis of mould and dampness exposure on asthma and allergy in eight European birth cohorts: an ENRIECO initiative. Allergy. 2011;66:1570-9.

13. Bousquet J, Anto J, Auffray C, Akdis M, Cambon-Thomsen A, Keil T, et al. MeDALL (Mechanisms of the Development of ALLergy): an integrated approach from phenotypes to systems medicine. Allergy. 2011;66:596-604.

14. Bousquet J, Anto J, Sunyer J, Nieuwenhuijsen M, Vrijheid M, Keil T Pooling Birth Cohorts in Allergy and Asthma: European UnionFunded Initiatives - A MeDALL, CHICOS, ENRIECO, and GA2LEN Joint Paper. Int Arch Allergy Immunol. 2013;161:1-10.

15. DeVries A, Wlasiuk G, Miller SJ, Bosco A, Stern DA, Lohman Cl, et al. Epigenome-wide analysis links SMAD3 methylation at birth to asthma in children of asthmatic mothers. J Allergy Clin Immunol. 2017;140:534-42.

16. Taussig LM, Wright AL, Holberg CJ, Halonen M, Morgan WJ, Martinez FD Tucson children's respiratory study: 1980 to present. J Allergy Clin Immunol. 2003;111:661-75.

17. Kooijman MN, Kruithof CJ, van Duijn CM, Duijts L, Franco OH, van ljzendoorn $\mathrm{MH}$, et al. The Generation R Study: design and cohort update 2017. Eur J Epidemiol. 2016;31:1243-64.

18. Agusti A, Faner R COPD beyond smoking: new paradigm, novel opportunities. Lancet Respir Med. 2018;6:324-6.

19. Agusti A, Pavord ID Do we really need a new classification of airway diseases? Lancet Respir Med. 2018;6:891-93.

20. Pavord ID, Beasley R, Agusti A, Anderson GP, Bel E, Brusselle $G$, et al. After asthma: redefining airways diseases. Lancet. 2018;391:350-400.

21. Moffatt MF, Kabesch M, Liang L, Dixon AL, Strachan D, Heath S, et al. Genetic variants regulating ORMDL3 expression contribute to the risk of childhood asthma. Nature. 2007:448:470.

22. Thomsen SF, Sluis VS, O. K-K, Skytthe A, Backer V. Estimates of asthma heritability in a large twin sample. Clin Exp Allergy. 2010;40:1054-61.

23. Martinez FD, Holberg CJ, Halonen M, Morgan WJ, Wright AL, Taussig LM. Evidence for Mendelian inheritance of serum IgE 
levels in Hispanic and non-Hispanic white families. Am J Hum Genet. 1994;55:555-65.

24. Moffatt MF, Gut IG, Demenais F, Strachan D, Bouzigon E, Heath S, et al. A large-scale, consortium-based genomewide association study of asthma. New Eng J Med. 2010;363:1211-21.

25. Schmitz J, Owyang A, Oldham E, Song Y. Immunity M-E IL-33, an interleukin-1-like cytokine that signals via the IL-1 receptorrelated protein ST2 and induces T helper type 2-associated cytokines. Immunity. 2005.

26. Dijk NF, Xu C, Melén E, Carsin A-E, Kumar A, Nolte IM, et al. Genetic regulation of IL1RL1 methylation and IL1RL1-a protein levels in asthma. Eur Respir J. 2018;51:1701377.

27. Zhang Y, Willis-Owen SAG, Spiegel S, Lloyd CM, Moffatt MF, Cookson W. The ORMDL3 Asthma Gene Regulates ICAM1 and has Multiple Effects on Cellular Inflammation. Am J Respir Crit Care Med. 2018; In Press.

28. Novotny LA, Bakaletz LO. Intercellular adhesion molecule 1 serves as a primary cognate receptor for the Type IV pilus of nontypeable Haemophilus influenzae. Cell Microbiol. 2016;18:1043-55.

29. Hilty M. Burke C, Pedro H, Cardenas P, Bush A, bossley C, et al. Disordered microbial communities in asthmatic airways. PLOS ONE. 2010;5:e8758.

30. Koppelman GH, Meyers DA, Howard TD, Zheng LS, Hawkins GA, Ampleford EJ, et al. Identification of PCDH1 as a Novel Susceptibility Gene for Bronchial Hyperresponsiveness. Am J Respir Crit Care Med. 2009:180:929-35.

31. Schieck M, Michel S, Suttner K, Illig T, Zeilinger S, Franke A, et al. Genetic variation in TH17 pathway genes, childhood asthma, and total serum IgE levels. J Allergy Clin Immunol. 2014;133:888-91.

32. Wu C-C, Chen R-F, Kuo H-C. Different Implications of Paternal and Maternal Atopy for Perinatal IgE Production and Asthma Development. Clin Dev Immunol. 2012;132142.

33. Abramson MJ, Schindler C, Schikowski T, Bircher AJ, Burdet $L$, Gerbase MW, et al. Rhinitis in Swiss adults is associated with asthma and early life factors, but not second hand tobacco smoke or obesity. Allergol Int. 2016;65:192-8.

34. Traherne JA, Hill MR, Hysi P, D'Amato M, Broxholme J, Mott R, et al. LD mapping of maternally and non-maternally derived alleles and atopy in FceRI- $\beta$. Hum Mol Genet. 2003;12:2577-85.

35. Wang Q-P, Wu K-M, Li Z-Q, Xue F, Chen W, Ji H, et al. Association between maternal allergic rhinitis and asthma on the prevalence of atopic disease in offspring. Int Arch Allergy Immunol. 2012;157:379-86.

36. Sunyer J, Antó JM, Harris J, Torrent M, Vall O, Cullinan $P$, et al. Maternal atopy and parity. Clin Exp Allergy. 2001;31:1352-5.

37. Karmaus W, Eneli I. Maternal atopy and the number of offspring: Is there an association? Pediatr Allergy Immunol. 2003; 14:470-4.

38. Litonjua AA, Carey VJ, Burge HA, Weiss ST, Gold DR. Parental history and the risk for childhood asthma. Does mother confer more risk than father? Am J Respir Crit Care Med. 1998;158:176-81.

39. Lim RH, Kobzik L, Dahl M. Risk for Asthma in Offspring of Asthmatic Mothers versus Fathers: A Meta-Analysis. PLOS ONE. 2010;5:e10134.

40. Liu X, Agerbo E, Schlünssen V, Wright RJ, Li J, Munk-Olsen T. Maternal asthma severity and control during pregnancy and risk of offspring asthma. J Allergy Clin Immunol. 2018; 141:886-92.

41. Jr RD, Faksh A, Vogel E, Martin RJ, Pabelick CM, Prakash YS Perinatal factors in neonatal and pediatric lung diseases. Expert Rev of Respir Med. 2014;7:515-31.

42. Turner SW, Campbell D, Smith N, Craig LCA, McNeill G, Forbes $\mathrm{SH}$, et al. Associations between fetal size, maternal $\alpha$-tocopherol and childhood asthma. Thorax. 2010;65:391-7.

43. Wolsk HM, Chawes BL, Litonjua AA, Hollis BW, Waage J, Stokholm J, et al. Prenatal vitamin D supplementation reduces risk of asthma/recurrent wheeze in early childhood: $A$ combined analysis of two randomized controlled trials. PLOS ONE. 2017:12:e0186657.

44. Chawes BL, Bønnelykke K, Stokholm J, Vissing NH, Bjarnadóttir E, Schoos A-MM, et al. Effect of Vitamin D3 Supplementation During Pregnancy on Risk of Persistent Wheeze in the Offspring: A Randomized Clinical Trial. JAMA. 2016;315:35361.

45. Litonjua AA, Lange NE, Carey VJ, Brown S, Laranjo N, Harshfield BJ, et al. The Vitamin D Antenatal Asthma Reduction Trial (VDAART): Rationale, design, and methods of a randomized, controlled trial of vitamin D supplementation in pregnancy for the primary prevention of asthma and allergies in children. Contemp Clin Trials. 2014;38:37-50.

46. Bunyavanich S, Rifas-Shiman SL, Platts-Mills TA, Workman L, Sordillo JE, Camargo CA, et al. Peanut, milk, and wheat intake during pregnancy is associated with reduced allergy and asthma in children. J Allergy Clin Immunol. 2014;133:137382.

47. Kumar R, Yu Y, Story RE, Pongracic JA, Gupta R, Pearson C, et al. Prematurity, chorioamnionitis, and the development of recurrent wheezing: A prospective birth cohort study. J Allergy Clin Immunol. 2008;121:878-84.

48. Gray LEK, O'Hely M, Ranganathan S, Sly P, Vuillermin P. The Maternal Diet, Gut Bacteria, and Bacterial Metabolites during Pregnancy Influence Offspring Asthma. Front Immunol. 2017;8:365.

49. Stokholm J, Sevelsted A, Bønnelykke K, Bisgaard H Maternal propensity for infections and risk of childhood asthma: a registry-based cohort study. Lancet Respir Med. 2014;2:6317.

50. Tong VT, Jones JR, Dietz PM, D'Angelo D, Bombard JM. (CDC) CfDCaP Trends in smoking before, during, and after pregnancy-Pregnancy Risk Assessment Monitoring System (PRAMS), United States, 31 sites, 2000-2005. MMWR Surveill Summ. 2009;58:1-29.

51. Landau LI. Tobacco smoke exposure and tracking of lung function into adult life. Paediatr Respir Rev. 2008;9:39-43.

52. Burke $H$, Leonardi-Bee J, Hashim A, Pine-Abata $H$, Chen $Y$, Cook DG, et al. Prenatal and passive smoke exposure and incidence of asthma and wheeze: systematic review and meta-analysis. Pediatrics. 2012;129:735-44.

53. Dehmel S, Nathan P, Bartel S, El-Merhie N, Scherb $H_{\text {, }}$ Milger $\mathrm{K}$, et al. Intrauterine smoke exposure deregulates lung function, pulmonary transcriptomes, and in particular insulin-like growth factor (IGF)-1 in a sex-specific manner. Sci Rep. 2018;8:7547.

54. Molero Y, Zetterqvist J, Lichtenstein P, Almqvist C, Ludvigsson JF. Parental nicotine replacement therapy and offspring 
bronchitis/bronchiolitis and asthma - a nationwide populationbased cohort study. Clin Epidemiol. 2018;10:1339-47.

55. Stensballe L, Simonsen J, Jensen SM, Bønnelykke K, Bisgaard $H$. Use of Antibiotics during Pregnancy Increases the Risk of Asthma in Early Childhood. J Pediatr. 2013;162:832-8.

56. Zhao D, Su H, Cheng J, Wang X, Xie M, Li K, et al. Prenatal antibiotic use and risk of childhood wheeze/asthma: A metaanalysis. Pediatr Allergy Immunol. 2015;26:756-64.

57. Cheelo M, Lodge CJ, Dharmage SC, Simpson JA, Matheson M, Heinrich J, et al. Paracetamol exposure in pregnancy and early childhood and development of childhood asthma: a systematic review and meta-analysis. Arch Dis Child. 2015;100:81-9.

58. Eyers S, Weatherall M, Jefferies S, Beasley R. Paracetamol in pregnancy and the risk of wheezing in offspring: a systematic review and meta-analysis. Clin Exp Allergy. 2011;41:482-9.

59. Davidson L, Berkelhamer S. Bronchopulmonary Dysplasia: Chronic Lung Disease of Infancy and Long-Term Pulmonary Outcomes. J Clin Med. 2017;6:4.

60. Stoll BJ, Hansen NI, Bell EF, Shankaran S, Laptook AR, Walsh $M C$, et al. Neonatal outcomes of extremely preterm infants from the NICHD Neonatal Research Network. Pediatrics. 2010;126:443-56.

61. Islam JY, Keller RL, Aschner JL, Hartert TV, Moore PE. Understanding the Short- and Long-Term Respiratory Outcomes of Prematurity and Bronchopulmonary Dysplasia. Am J Respir Crit Care Med. 2015;192:134-56.

62. Landry JS, Chan T, Lands L, Menzies D. Long-term impact of bronchopulmonary dysplasia on pulmonary function. Can Respir J. 2011;18:265-70.

63. Gough A, Linden M, Spence D, Patterson CC, Halliday HL, McGarvey LP. Impaired lung function and health status in adult survivors of bronchopulmonary dysplasia. Eur Respir J. 2014;43:808-16.

64. der Voort A, Arends LR, de Jongste JC, Annesi-Maesano I, Arshad HS, Barros $\mathrm{H}$, et al. Preterm birth, infant weight gain, and childhood asthma risk: A meta-analysis of 147,000 European children. J Allergy Clin Immunol. 2014;133:1317-29.

65. de Gonçalves D, Wandalsen G, Scavacini A, Lanza F, Goulart $A$, Solé $D$, et al. Pulmonary function in former very low birth weight preterm infants in the first year of life. Respir Med. 2018; 136:83-7.

66. Turner S, Fielding S, Devereux G. First trimester fetal size and prescribed asthma medication at 15 years of age. Eur Respir J. 2018;51:1701509.

67. Simpson A, Tan VY, Winn J, Svens 'en M, Bishop CM, Heckerman $D E$, et al. Beyond atopy: multiple patterns of sensitization in relation to asthma in a birth cohort study. Am J Respir Crit Care Med. 2010;181:1200-06.

68. Jackson DJ, Gangnon RE, Evans MD, Roberg KA, Anderson EL, Pappas TE, et al. Wheezing rhinovirus illnesses in early life predict asthma development in high risk children. Am J Respir Crit Care Med. 2008;178:667-72.

69. Johnston SL, Pattemore PK, Sanderson G, Smith S, Campbell MJ, Josephs LK, et al. The relationship between upper respiratory infections and hospital admissions for asthma: a time-trend analysis. Am J Respir Crit Care Med. 1996;154:654-60.

70. Martinez FD. Bending the twig does the tree incline: lung function after lower respiratory tract illness in infancy. Am J Respir Crit Care Med. 2017;195:154-5.
71. Schwartz J, Slater D, Larson TV, Pierson WE, Koenig JQ. Particulate air pollution and hospital emergency room visits for asthma in Seattle. Am Rev Respir Dis. 1993;147:826-31.

72. Atkinson RW, Anderson HR, Sunyer J, Ayres J, Baccini M, Vonk JM, et al. Acute effects of particulate air pollution on respiratory admissions: results from APHEA 2 project. Air pollution and health: a European approach. Am J Respir Crit Care Med. 2001;164:1860-6.

73. Pope CA III, Dockery DW, Spengler JD, Raizenne ME. Respiratory health and PM10 pollution: a daily time series analysis. Am Rev Respir Dis. 1991;144: 668-74.

74. Gauderman WJ, Urman R, Avol E, Berhane K, McConnell R, Rappaport $E$, et al. Association of improved air quality with lung development in children. N Engl J Med. 2015;372:905-13.

75. von Mutius E, Martinez FD, Fritzsch C, Nicolai T, Roell G, Thiemann $\mathrm{HH}$. Prevalence of asthma and atopy in two areas of West and East Germany. Am J Respir Crit Care Med. 1994;149:358-64.

76. Lampi J, Koskela H, Hartikainen AL, Ramasamy A, Couto Alves $A$, Järvelin $M R$, et al. Farm environment during infancy and lung function at the age of 31 : a prospective birth cohort study in Finland. BMJ Open. 2015;5(7):e007350.

77. Castro-Rodriguez JA, Holberg CJ, Wright AL, Martinez FD. A clinical index to define risk of asthma in young children with recurrent wheezing. Am J Respir Crit Care Med. 2000;162:1403-6.

78. Zeiger RS, Mauger D, Bacharier LB, Guilbert TW, Martinez FD, Lemanske RF Jr, et al. CARE Network of the National Heart, Lung, and Blood Institute. Daily or intermittent budesonide in preschool children with recurrent wheezing. N Engl J Med. 2011;365:1990-2001.

79. Guilbert TW, Morgan WJ, Zeiger RS, Mauger DT, Boehmer SJ, Szefler SJ, et al. Longterm inhaled corticosteroids in preschool children at high risk for asthma. N Engl J Med. 2006;354:198597.

80. Hiranrattana A, Stern DA, Guerra S, Halonen M, Wright AL, Daines $M$, et al. Alternaria sensitisation at age 6 years is associated with subsequent airway hyper-responsiveness in non-asthmatics. Thorax. 2018;73(12):1170-3.

81. Maas T, Kaper J, Sheikh A, Knottnerus JA, Wesseling G, Dompeling $E$, et al. Mono and multifaceted inhalant and/or food allergen reduction interventions for preventing asthma in children at high risk of developing asthma. Cochrane Database Syst Rev. 2009;(3):CD006480.

82. Valovirta E, Petersen TH, Piotrowska T, Laursen MK, Andersen JS, Sorensen HF, et al. Results from the 5-year SQ grass sublingual immunotherapy tablet asthma prevention (GAP) trial in children with grass pollen allergy. J Allergy Clin Immunol. 2018;141(2):529-38.e13.

83. Carr TF, Stern DA, Halonen M, Wright AL, Martinez FD. Nonatopic Rhinitis at Age 6 is Associated with Subsequent Development of Asthma. Clin Exp Allergy 2018 2019;49(1): 35-43.

84. Lukkarinen $M$, Koistinen $A$, Turunen $R$, Lehtinen $P$, Vuorinen $T$, Jartti $T$, et al. Rhinovirus-induced first wheezing episode predicts atopic but not nonatopic asthma at school age. J Allergy Clin Immunol. 2017;140(4):988-95.

85. Berry CE, Billheimer D Jenkins IC, Lu ZJ, Stern DA, Gerald LB, et al. A Distinct Low Lung Function Trajectory from Childhood 
to the Fourth Decade of Life. Am J Respir Crit Care Med. 2016;194(5):607-12.

86. Bacharier LB, Guilbert TW, Mauger DT, Boehmer S, Beigelman A, Fitzpatrick AM, et al. Early Administration of Azithromycin and Prevention of Severe Lower Respiratory Tract Illnesses in Preschool Children With a History of Such Illnesses: A Randomized Clinical Trial. JAMA. 2015;314(19):2034-44.

87. Hodge L, Salome CM, Peat JK, Haby MM, Xuan W, Woolcock AJ. Consumption of oily fish and childhood asthma risk. Med J Aust. 1996;164(3):137-40.

88. Lang JE, Fitzpatrick AM, Mauger DT, Guilbert TW, Jackson DJ, Lemanske RF Jr, et al. Overweight/obesity status in preschool children associates with worse asthma but robust improvement on inhaled corticosteroids. J Allergy Clin Immunol. 2018;141(4):1459-67.

89. Guerra S, Stern DA, Zhou M, Sherrill DL, Wright AL, Morgan WJ, et al. Combined effects of parental and active smoking on early lung function deficits: a prospective study from birth to age 26 years. Thorax. 2013;68(11):1021-8.

90. Voraphani N, Stern DA, Wright AL, Guerra S, Morgan WJ, Martinez FD. Risk of current asthma among adult smokers with respiratory syncytial virus illnesses in early life. Am J Respir Crit Care Med. 2014;190(4):392-8.

91. Guerra S, Wright AL, Morgan WJ, Sherrill DL, Holberg CJ, Martinez FD. Persistence of asthma symptoms during adolescence: role of obesity and age at the onset of puberty. Am J Respir Crit Care Med. 2004;170(1):78-85.

92. Wei J, Gerlich J, Genuneit J, Nowak D, Vogelberg C, von Mutius

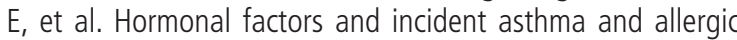
rhinitis during puberty in girls. Ann Allergy Asthma Immunol. 2015;115(1):21-7.

93. Svanes Ø, Skorge TD , Johannessen A, Bertelsen RJ, Bråtveit M, Forsberg B, et al. Respiratory Health in Cleaners in Northern Europe: Is Susceptibility Established in Early Life? PLoS One. 2015; 10(7):e0131959.

94. Agusti, A, Faner R. COPD beyond smoking: new paradigm, novel opportunities. Lancet Respir Med. 2018;6:324-6.

95. Pavord, ID, Beasley R, Agusti A, Anderson GP, Bel E, Brusselle $\mathrm{G}$, et al. After asthma - redefining airways diseases. A Lancet commission. Lancet. 2017:391:350-400.

\section{Alvar Agustí}

Respiratory Institute

Hospital Clinic

Villarroel 170

08036 Barcelona, Spain

E-mail: aagusti@clinic.cat 